\title{
Influence of effective width of flange on calculation and reinforcement dimensioning of beam of reinforced concrete frame
}

\author{
Maciej Tomasz Solarczyk \\ Department of Concrete Structures; Faculty of Civil and Environmental Engineering; \\ Gdańsk University of Technology; 11/12 Narutowicza St., 80-233 Gdańsk, Poland; \\ maciej.solarczyk@pg.edu.pl (iD)0000-0001-6070-0736
}

\begin{abstract}
The paper analyses the influence of modelling the cross-section of a beam in two-storey reinforced concrete frame of industrial warehouse with dimensions: $18.0 \mathrm{~m} \times$ $32.0 \mathrm{~m}$ using bar elements on the results of bending moments, the value of elastic deflection and the dimensioning of reinforcement due to bending. Six options were considered: a beam as a rectangular section and five T-beam variants with different definitions of effective flange width. The differences in obtained results were commented on. Conclusions useful for the designing of reinforced concrete structures were presented. The procedure for determining the effective flange width in the context of PN-EN 1992-1-1:2008 and PN-B 03264:2002 standards with a commentary on the use of effective flange width in calculations and construction of reinforcement in reinforced concrete structures were described. Brief description of determining the reinforcement due to bending according to the simplified method given in PN-EN 1992-11:2008 was presented. In addition, the standard formula for determining the minimum cross sectional area of reinforcement (9.1N) in PN-EN 1992-1-1:2008 with a proposal for its strict determination for the T-beam with the flange in tension was analysed.
\end{abstract}

Keywords: reinforced concrete structures; effective width of flange, minimum cross sectional area of reinforcement, PN-EN 1992-1-1:2008, PN-B 03264:2002

\section{Introduction}

Nowadays, designers of engineering structures have a wide range of programs for determination of internal forces and reinforcement dimensioning in reinforced concrete structures [1], [2]. The use of spatial calculation models of objects is becoming increasingly popular. By creating a single design file, the designer has a full spectrum of internal forces values. However, it also has its disadvantages - due to the multitude of design combinations, the interpretation of results may be difficult [3]. The calculation time of spatial models is substantial. Creating a 3D model requires considerable experience for the designer. It is necessary to accurately 
map the location of subsequent elements of the structural system, which was pointed out by Starosolski [4], Kossakowski [5], [6], Godycki-Ćwirko et al. [7], Nagrodzka-Godycka et al. [8] and Wojdak [9] in their publications.

In the case of frame structures, they are most often modelled as plane frame. This approach allows the subsequent parts of the frame to be modelled as beam elements. The most important task in a cast structures is to determine the cross section of beam of the frame between the beam and floor slab.

The paper analyses the effect of the beam cross section of a reinforced concrete frame on the results of internal forces, elastic deflection values and reinforcement dimensioning. Six models with different definition of effective width of the flange have been analysed. An in-depth numerical analysis of the effective flange width (spatial model) is presented in [10].

In addition, the paper presents a procedure for determining the minimum cross-sectional area of the longitudinal tension reinforcement according to the recommendations of standard [11] for a T-section with the flange in tension. The issue of minimum reinforcement due to cracking was raised by Knauff [12], [13], [14] and [15] in his publications.

\section{Effective width of flange in standard terms}

The effective width of flange, in addition to its use in the definition of the construction model, is necessary to determine the dimensioning of the reinforcement due to bending. Section 3.2.3 of [16] states that: The appropriate flange width calculated for considered span and the position of the section should always be used to check the ultimate resistance of the beam sections.

Moreover, the effective width is necessary for determining the minimum cross-sectional area of longitudinal tension reinforcement according to the formula (9.1N) in [11]. It depends on the size $b_{\mathrm{t}}$ - mean width of the tension zone. Its determination may cause some complications in case of the flange in tension.

According to the recommendations of standard [11], section 9.2.1.2 (2), the effective width is additionally used to determine the width at which the tension reinforcement is to be spread at intermediate supports of continuous beams (Fig. 1.): At intermediate supports of continuous beams, the total area of tension reinforcement $A_{\mathrm{s}}$ of a flanged cross-section should be spread over the effective width of flange. Part of it may be concentrated over the web width. 


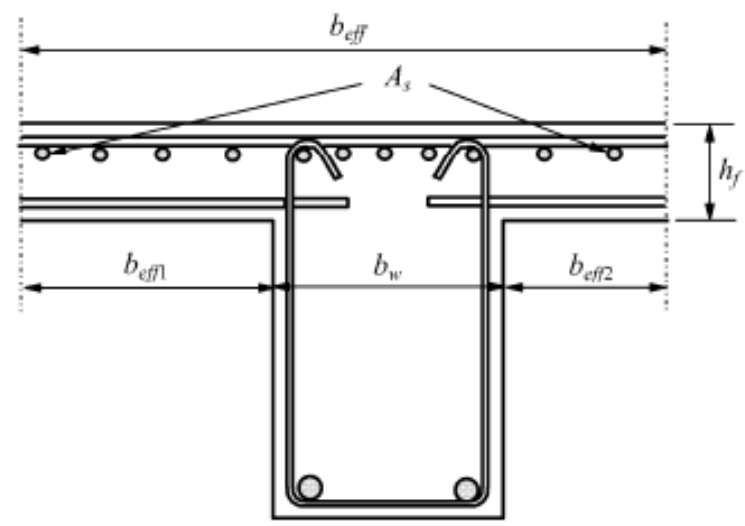

Fig. 1. Placing of tension reinforcement in flanged cross-section; source: Figure 9.1 in [11]

The effective flange width must be determined to define the longitudinal shear stress at the junction between one side of a flange and the web in the shear between web and flanges procedure according to clause 6.2 .4 in [11].

The effective flange overhang can be determined from formula (5.7a) in [11]:

$b_{\text {eff }, i}=\min \left\{\begin{array}{c}0,2 \cdot b_{i}+0,1 \cdot l_{0} \\ 0,2 \cdot l_{0} \\ b_{i}\end{array}\right.$

The effective flange width can be determined from formula (5.7) in [11]:

$b_{\text {eff }}=\min \left\{\begin{array}{c}\sum b_{\text {eff }, i}+b_{w} \\ b\end{array}\right.$

The designations given in formulas (1) and (2) are defined in Fig. 2 and Fig. 3.

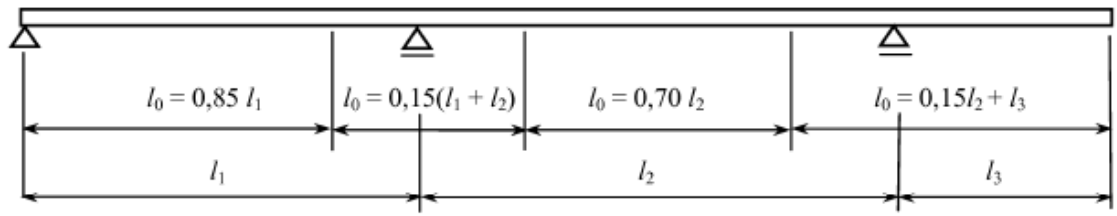

Fig. 2. Definition of $l_{0}$ for calculation of effective flange width; source: Figure 5.2 in [11] 




Fig. 3. Effective flange width parameters; source: Figure 5.3 in [11]

Standard [17], in addition to the recommendations given in [11], introduces an additional restriction on the width of the flange when checking the ultimate limit state (ULS). It is to be assumed that for a double-sided overhang $b_{\text {eff1 }}$ or $b_{\text {eff2 }} \leq 6 h_{\mathrm{f}}$ (according to formula (19a) in [17]), and for a single-sided overhang $b_{\text {eff } 1} \leq 4 h_{\mathrm{f}}$ (according to formula (19b) in [17]). The publication [18] treats the consequences of the choice of design standards [11] or [17] for material consumption on the example of a flat ceiling.

\section{Parameters of the analyzed reinforced concrete plane frame}

The paper analyses the influence of modelling the beam of a reinforced concrete plane frame using bar elements on the results of internal forces - bending moments and elastic deflection values. The calculations were performed in Autodesk Robot Structural Analysis (ARSA) version 2015 [1]. The object of the analysis is two-storey frame in building with dimensions (width $\times$ length): $18.0 \mathrm{~m} \times 32.0 \mathrm{~m}$ forming part of construction of an industrial warehouse. A single beam has a span $L=9.0 \mathrm{~m}$. Subsequent frames are set at a distance of $B=4.0 \mathrm{~m}$. The structure is made of concrete class C25/30. Steel class A-IIIN, grade $\mathrm{B} 500 \mathrm{SP}$ is used to dimensioning the reinforcement. The storey height is $H=4.0 \mathrm{~m}$. The supports of the frame beams are reinforced concrete columns with dimensions (width $\times$ height): $30 \mathrm{~cm} \times 60 \mathrm{~cm}$. The columns are fixed in foundation footings. The total height of the frame beam is $h=75 \mathrm{~cm}$. The width of the beam web is $b_{\mathrm{w}}=30 \mathrm{~cm}$. The height of the flange which is a one-way floor slab is equal to $15 \mathrm{~cm}$ (Fig. 4).

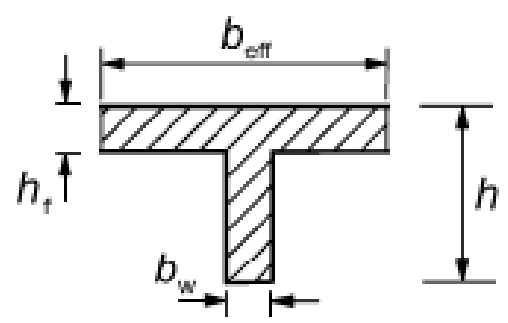

Fig. 4. Description of dimensions of the T-section; source: Figure 5.3 in [11] 
A steel truss with a span of $18.0 \mathrm{~m}$ was used as a construction of roofing. The following were assumed as the loads: the self-weight of the structure (from the ARSA program excluding the beam - a characteristic load of $19.5 \mathrm{kN} / \mathrm{m}$ was transferred on it). Also added the complementary load from the finishing layers located on the floor: $1.5 \mathrm{kN} / \mathrm{m}^{2}$ (estimate; characteristic value), which gave the load on the frame of $6 \mathrm{kN} / \mathrm{m}$ and an imposed load - according to Table 6.3 in [19], the areas where goods can be accumulated belong to category E1; according to Table 6.4 in [19], the characteristic imposed load on floor for this category is $7.5 \mathrm{kN} / \mathrm{m}^{2}$; which gave the load on the frame of $30 \mathrm{kN} / \mathrm{m}$. The complementary load from the finishing layers of roof is assumed as characteristic value equal $5 \mathrm{kN} / \mathrm{m}$.

Following calculation combinations were assumed (according to point 6.4.3.2 in [20]): ULS1 with imposed load on the left span of frame beam, ULS2 with imposed load on the right span of frame beam and ULS3 with imposed load on both spans simultaneously.

Due to the course of the bending moments in the frame beam (rigid connection of external column to the beam), the distances $l_{0}$ between points of zero bending moment have been established by modifying Fig. 5.2 in [11] as shown in Fig. 5.

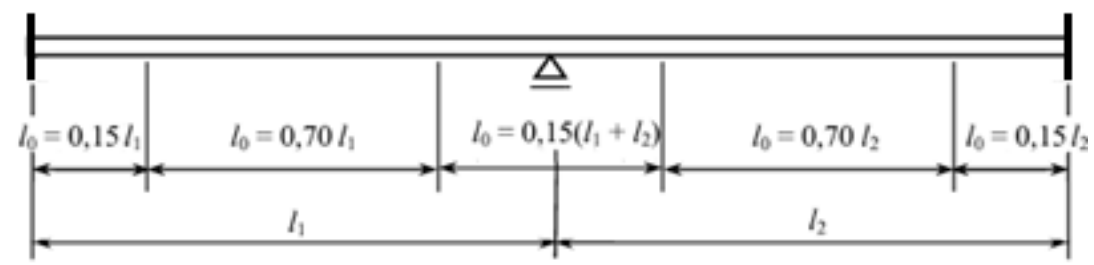

Fig. 5. Definition of $l_{0}$ for calculation of effective flange width - adaptation to the task under consideration; source: Figure 5.2 in [11]

The article analyses six different ways of modelling a beam of reinforced concrete plane frame using bar elements:

- variant 1 - frame beam assumed as a rectangular beam with dimensions $b_{\mathrm{w}} \times h$ (Fig. 6),

- variant 2 - frame beam assumed as a T-section with a flange width equal to the spacing of successive frames $B=4.0 \mathrm{~m}$,

- variant 3 - frame beam assumed as a T-section with a flange with widths determined by the standard [11] with the definition of different widths for subsequent sections between points of zero bending moment using recommendations [11] (Fig. 8),

- variant 4 - frame beam assumed as a T-section with a flange with widths determined by the standard [11] with definition of different widths for subsequent sections between points of zero bending moment using the bending moment diagram obtained from variant 1 of the calculations,

- variant 5 - frame beam assumed as a T-section with a flange with widths determined by the standard [11] with definition of different widths for subsequent sections between points of zero bending moment using the recommendations [11], but taking into account a gradual change of the effective width of flange along the length of the beam (varying linearly from the support to the middle of the span), 
- variant 6 - frame beam assumed as a T-section with a flange along the whole length of an element of width equal to the effective width of flange calculated using the standard [11] in the span section.

The calculations in variant 3 fulfil the recommendations given in section 4.4.3.2 in [17]: For the calculations, the effective flange width $b_{\text {eff }}$ in T-sections-constant over the entire length of the element under consideration where the moment of the same sign occurs - may be taken.

Variant 6 of the calculations fulfils the recommendation of clause 5.3.2.1 (4) in [11]: For structural analysis, where a great accuracy is not required, a constant width may be assumed over the whole span. The value applicable to the span section should be adopted, and from Section 9.2.6 in [21]: In the calculation of statically indeterminate system, the cross-section is usually assumed to be constant over the entire length, and in the calculation of beam deflections, the decisive stiffness is determined from the cross-section in the span.

As shown in Table 1. the most similar values of the distances $l_{0}$ to the ones recommended in [11] are obtained for the calculation in the ULS3 combination corresponding to the location of the imposed load on both spans which leads to extreme bending moments at the inner support. These values were used to calculate the effective flange width in variant 4 .

Table 1. Comparison of $l_{0}$ values for different calculation variants

\begin{tabular}{llll}
\hline Calculation variant & $\begin{array}{l}\text { External support } \\
\text { node 2 and 6 } \\
- \text { see Fig. 6 }\end{array}$ & $\begin{array}{l}\text { Span between } \\
\text { nodes 2 and 4; } \\
4 \text { and 6 }\end{array}$ & $\begin{array}{l}\text { Inner } \\
\text { support } \\
\text { node 4 }\end{array}$ \\
\hline As recommended in [11], Fig. 5 & $1.35 \mathrm{~m}$ & $6.3 \mathrm{~m}$ & $2.7 \mathrm{~m}$ \\
\hline Variant 1), combination ULS1 & $1.38 \mathrm{~m}$ & $6.0 \mathrm{~m}$ & $4.53 \mathrm{~m}$ \\
\hline Variant 1), combination ULS2 & $2.08 \mathrm{~m}$ & $4.01 \mathrm{~m}$ & $4.54 \mathrm{~m}$ \\
\hline Variant 1), combination ULS3 & $1.46 \mathrm{~m}$ & $5.54 \mathrm{~m}$ & $4.0 \mathrm{~m}$ \\
\hline
\end{tabular}

Table 2 shows a comparison of the effective width of flange $b_{\text {eff }}$ calculated for the value $l_{0}$ determined according to the recommendations [11] and for the moment diagram in the ULS3 combination in variant 1 of the calculation. The greatest differences occur in the effective width of flange for the inner support - about $25 \%$.

Table 2. Comparison of effective width of flange $b_{\text {eff }}$ values in characteristic points of beam of reinforced concrete frame

\begin{tabular}{llll}
\hline Calculation variant & $\begin{array}{l}\text { External support } \\
\text { node 2 and 6 } \\
- \text { see Fig. 6 }\end{array}$ & $\begin{array}{l}\text { Span between } \\
\text { nodes 2 and 4; } \\
4 \text { and 6 }\end{array}$ & $\begin{array}{l}\text { Inner } \\
\text { support } \\
\text { node 4 }\end{array}$ \\
\hline As recommended in [11], Fig. 5 & $84 \mathrm{~cm}$ & $230 \mathrm{~cm}$ & $138 \mathrm{~cm}$ \\
\hline Variant 1, combination ULS3 & $88.4 \mathrm{~cm}$ & $214.8 \mathrm{~cm}$ & $184 \mathrm{~cm}$ \\
\hline
\end{tabular}

\section{Analysis of bending moments and elastic deflection in the frame}

Fig. 6 and Fig. 8 show the geometry of the analyzed reinforced concrete frame in variant 1 and 3 of calculations respectively. Fig. 7 and Fig. 9 show bending moment envelope from the combination of ULS1, ULS2 and ULS3 in variant 1 and 3 of calculations respectively. 


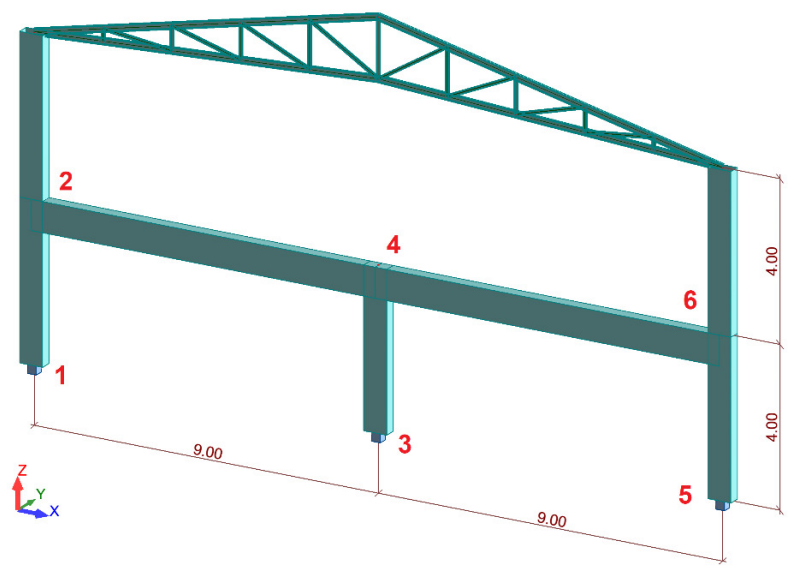

Fig. 6. Geometry of reinforced concrete frame in variant 1 of calculations

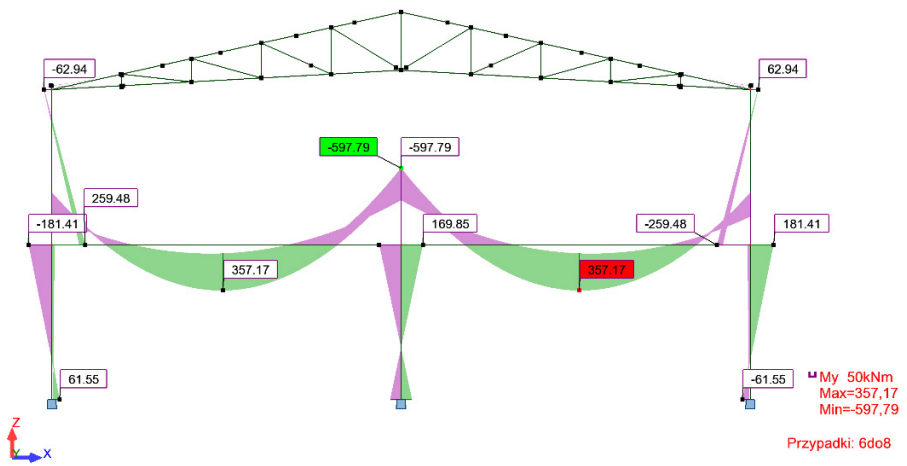

Fig. 7. Envelope of bending moments for calculations in variant 1

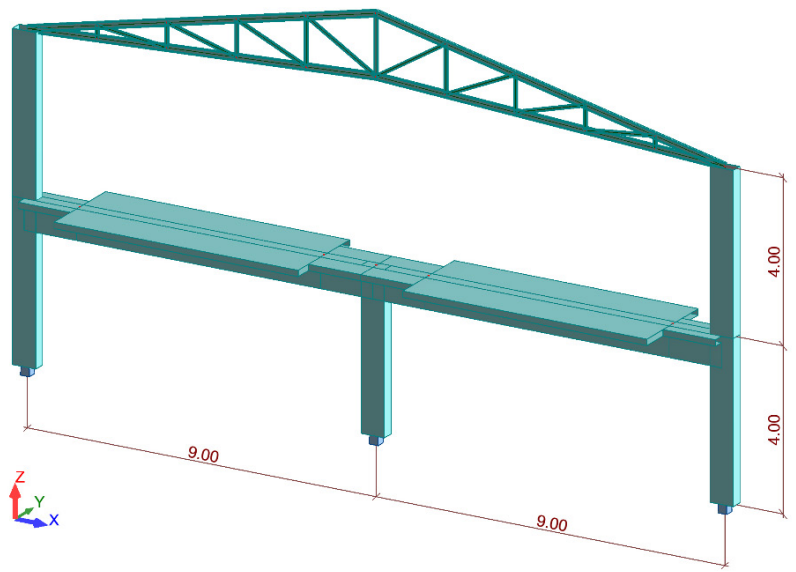

Fig. 8. Geometry of reinforced concrete frame in variant 3 of calculations 




Fig. 9. Envelope of bending moments for calculations in variant 3

Table 3 presents the values of bending moments $[\mathrm{kNm}]$ and elastic deflection $[\mathrm{cm}]$ read from the calculations results in the ARSA program at characteristic points of the considered reinforced concrete frame, depending on the calculation variant (see also Fig. 7 and Fig. 9).

Table 3. List of bending moments $[\mathrm{kNm}]$ and elastic deflection $[\mathrm{cm}]$ at characteristic points of considered reinforced concrete frame

\begin{tabular}{lcccccc}
\hline Location & Variant 1 & Variant 2 & Variant 3 & Variant 4 & Variant 5 & Variant 6 \\
\hline $\begin{array}{l}\text { External support } \\
\text { (node 2 and 6 - see Fig. 6) }\end{array}$ & 407.05 & 327.99 & 336.33 & 339.5 & 333.28 & 340.27 \\
\hline Span (between nodes 2 and 4; 4 and 6) & 357.17 & 399.56 & 405.06 & 394.94 & 402.29 & 393.33 \\
\hline Inner support (node 4) & 597.79 & 632.31 & 603.61 & 620.34 & 614.74 & 627.28 \\
\hline $\begin{array}{l}\text { External column upper node } \\
\text { (node 2 and 6) }\end{array}$ & 181.41 & 121.91 & 128.78 & 132.45 & 127.6 & 130.47 \\
\hline $\begin{array}{l}\text { External column lower node } \\
\text { (node 1 and 5) }\end{array}$ & 61.55 & 47.61 & 51.02 & 51.39 & 49.3 & 49.76 \\
\hline $\begin{array}{l}\text { Inner column upper node } \\
\text { (node 4) }\end{array}$ & 169.85 & 105.85 & 114.92 & 120.95 & 119.56 & 114.46 \\
\hline $\begin{array}{l}\text { Inner column lower node } \\
\text { (node 3) }\end{array}$ & 85.72 & 59.19 & 63.07 & 66.18 & 65.02 & 62.96 \\
\hline $\begin{array}{l}\text { Span - elastic deflection } \\
\text { (between nodes 2 and 4; 4 and 6) }\end{array}$ & 0.73 & 0.37 & 0.42 & 0.44 & 0.44 & 0.41 \\
\hline
\end{tabular}

Table 4 compares the percentage differences of bending moments and deflections with the calculation in variant 6 (according to the simplified recommendation from section 5.3.2.1 (4) in [11]) - considered to be the effective solution in terms of the amount of work involved in creating the calculation model and generating loads. The positive percentage difference represents an overestimation of the magnitude, while the negative magnitude represents an underestimation. 
Table 4. Comparison of bending moment values and elastic deflection in the span in relation to the variant 6 of calculations

\begin{tabular}{lccccc}
\hline Location & Variant 1 & Variant 2 & Variant 3 & Variant 4 & Variant 5 \\
\hline $\begin{array}{l}\text { External support } \\
\text { (node 2 and 6 - see Fig. 6) }\end{array}$ & $19.63 \%$ & $-3.61 \%$ & $-1.16 \%$ & $-0.23 \%$ & $-2.05 \%$ \\
\hline $\begin{array}{l}\text { Span } \\
\text { (between nodes 2 and 4; 4 and 6) }\end{array}$ & $-9.19 \%$ & $1.58 \%$ & $2.98 \%$ & $0.41 \%$ & $2.28 \%$ \\
\hline \begin{tabular}{l} 
Inner support (node 4) \\
\hline $\begin{array}{l}\text { External column upper node } \\
\text { (node 2 and 6) }\end{array}$
\end{tabular} & $-4.70 \%$ & $0.80 \%$ & $-3.77 \%$ & $-1.11 \%$ & $-2.00 \%$ \\
\hline $\begin{array}{l}\text { External column lower node } \\
\text { (node 1 and 5) }\end{array}$ & $23.69 \%$ & $-4.32 \%$ & $2.53 \%$ & $3.28 \%$ & $-0.92 \%$ \\
\hline $\begin{array}{l}\text { Inner column upper node (node 4) } \\
\text { Inner column lower node (node 3) }\end{array}$ & $48.39 \%$ & $-7.52 \%$ & $0.40 \%$ & $5.67 \%$ & $4.46 \%$ \\
\hline $\begin{array}{l}\text { Span - elastic deflection } \\
\text { (between nodes 2 and 4; 4 and 6) }\end{array}$ & $76.15 \%$ & $-5.99 \%$ & $0.17 \%$ & $5.11 \%$ & $3.27 \%$ \\
\hline
\end{tabular}

The calculations in Variant 1 - rectangular beam, overwhelmingly exceed the bending moments compared to the calculations in Variant 6 . This is particularly true for columns, where the differences can be up to $50 \%$. For the beam, the span moment is lower by about $10 \%$ and at the internal support by about $5 \%$. In the case of the external support, the difference is much greater - an overvaluation of about $20 \%$. The magnitude of elastic deflection varies significantly - as much as about $80 \%$ of variant 1 revalues the deflection compared to variant 6 .

The calculations in Variant 2 for bending moments are similar to the values obtained from calculations in variant 6 , especially in the beam where the differences do not exceed $5 \%$. Slightly larger differences occur in the bending moments in the columns, but do not exceed $10 \%$. However, it is worth noting that this modelling of the beam results in an underestimation of the elastic deflection by about $10 \%$.

In variant 3 and variant 4 only in a few places the bending moments in the column are overestimated by more than $5 \%$.

The most accurate calculation model is variant 5 , but due to the difficulties in creating model and applying loads - it is not a solution often used in designing of structures. It is worth noting that the calculations in variant 6 in bending moments at each of the characteristic locations of the considered reinforced concrete frame do not exceed 5\%, which can be considered as a satisfactory degree of accuracy. Only the elastic deflection of the beam is overestimated by about $7 \%$.

\section{Reinforcement dimensioning due to bending using simplified method}

In this section, the procedure for dimensioning of reinforcement due to bending using simplified method is presented. 
Auxiliary coefficient (according to formula (4.51) in [22], taking into account the recommendations [11]):

$$
\mu_{e f f}=\frac{M_{E d}}{b \cdot d^{2} \cdot \eta \cdot f_{c d}}
$$

where: $M_{\mathrm{Ed}}-$ design value of the applied internal bending moment, $b$ - the width of the compression zone, $d$-effective depth of a cross-section, $\eta$ - coefficient defining the effective strength (according to formula (3.21) and (3.22) in [11]), $f_{\mathrm{cd}}$ - design value of concrete compressive strength (according to formula (3.15) in [11]).

Range of the effective compression zone (formula (4.52) in [22]):

$$
\xi_{\text {eff }}=1-\sqrt{1-2 \cdot \mu_{\text {eff }}}
$$

Limit range of the effective compression zone (according to formula (4.19) in [22], taking into account the recommendations [11]):

$$
\xi_{\text {eff }, \lim }=\lambda \cdot \frac{\varepsilon_{c u 3}}{\varepsilon_{c u 3}+\frac{f_{y d}}{E_{s}}}
$$

where: $\lambda$ - coefficient defining the effective height of the compression zone (according to formula (3.19) and (3.20) in [11]), $\varepsilon_{\mathrm{cu} 3}$ - ultimate compressive strain in the concrete for the bilinear stress-strain relation (according to Table 3.1 in [11]), $f_{\mathrm{yd}}-$ design yield strength of the reinforcement, $E_{\mathrm{s}}$ - design value of the modulus of elasticity of reinforcing steel (according to Section 3.2.7 (4) in [11]).

The cross-sectional area of the tension reinforcement when $\xi_{\text {eff }} \leq \xi_{\text {eff,lim }}$ (according to formula (4.52) in [22], taking into account recommendations [11]):

$$
A_{s 1}=\xi_{\text {eff }} \cdot d \cdot b \cdot \frac{\eta \cdot f_{c d}}{f_{y d}}
$$

The minimum cross-sectional area of the tension reinforcement is determined by the formula $(9.1 \mathrm{~N})$ in [11]:

$$
A_{s, \min }=\max \left\{\begin{array}{c}
0,26 \cdot \frac{f_{c t m}}{f_{y k}} \cdot b_{t} \cdot d \\
0,0013 \cdot b_{t} \cdot d
\end{array}\right.
$$

where: $f_{\mathrm{ctm}}-$ mean value of axial tensile strength of concrete, $f_{\mathrm{yk}}-$ characteristic yield strength of the reinforcement, $b_{\mathrm{t}}$ - mean width of the tension zone; for a T-beam with the flange in compression, only the width of the web is taken into account in calculating the value of $b_{\mathrm{t}}$.

It should be noted that standard [11] also provides a simplified method to determine the minimum cross-sectional area of the tensile reinforcement. Note 2 to Section 9.2.1.1 in [11] states that: Alternatively, for secondary elements, where some risk of brittle failure may be accepted, $A_{\mathrm{s}, \min }$ may be taken as 1,2 times the area required in ULS verification. However, the standard [11] does not define the term "secondary elements" anywhere, which is a serious problem in the interpretation of this recommendation. The minimum reinforcement should 
be used to limit the effects of unexpected change in the stiffness of the element during the transition from phase I (uncracked) to phase II (cracked) [23].

Determining the mean width of the tension zone $b_{\mathrm{t}}$ in the case of a flange in the tension may cause some design complications. The simplification of considering only the web part of the section is on the unsafe side - it underestimates the value of the minimum cross-section area of the tension reinforcement. Formula $(9.1 \mathrm{~N})$ in [11] is given for the rectangular section. It can be determined by calculating the cracking moment on the basis of theory of phase I and on the basis of theory of phase II.

Cracking moment calculated according to the theory of phase I (right before cracking):

$$
M_{c r}=f_{c t m} \cdot W_{x}
$$

where: $W_{\mathrm{x}}$ - section modulus before cracking calculated for the extreme tensile fibers of the element.

Cracking moment calculated according to the theory of phase II (right after cracking):

$$
M_{c r}=A_{s 1} \cdot f_{y k} \cdot\left(d-\frac{x_{I I}}{3}\right)
$$

where: $x_{\text {II }}-$ height of the compression zone after the cracking (phase II).

By comparing the values obtained from formulas (8) and (9), it can be obtained a formula for determining the minimum cross-sectional area of the tension reinforcement:

$$
A_{s, \min }=\frac{f_{c t m} \cdot W_{x}}{f_{y k} \cdot\left(d-\frac{x_{I I}}{3}\right)}
$$

The value of the minimum cross-sectional area of the tension reinforcement given by formula (10) depends on the material data (mean value of axial tensile strength of concrete and characteristic yield strength of the reinforcement), but also on geometrical values. The height of the compression zone in phase II depends on the cross-sectional area of the tension reinforcement (and so on $A_{\mathrm{s}, \mathrm{min}}$ ). Therefore, equation (10) becomes an iterative equation. This is not a significant problem in nowadays numerical calculations.

The procedure of determining the minimum cross-sectional area of the tension reinforcement for the tension of the upper fibres (according to Fig. 4) of the T-section is presented below.

First moment of area in phase I calculated in relation to the upper edge:

$$
S_{x}=b_{e f f} h_{f} \frac{h_{f}}{2}+b_{w} h_{w}\left(h_{f}+\frac{h_{w}}{2}\right)+\left(\alpha_{e}-1\right) A_{s, \min } a_{1}
$$

where: $h_{\mathrm{w}}$ - web height; $h_{\mathrm{w}}=h-h_{\mathrm{f}}, \alpha_{\mathrm{e}}-$ the ratio of modulus of elasticity of reinforcing steel to secant modulus of elasticity of concrete: $\alpha_{\mathrm{e}}=E_{\mathrm{s}} / E_{\mathrm{cm}}$; if the cracking is expected to appear in the element for loads with duration causing creep, the effective modulus of elasticity ratio can be used: $\alpha_{\mathrm{e}}=E_{\mathrm{s}} / E_{\mathrm{c}, \text { eff }}$, where the effective modulus of elasticity for concrete can be determined from formula (7.20) in [11]: $E_{\mathrm{c}, \mathrm{eff}}=E_{\mathrm{cm}} /\left(1+\varphi\left(\infty, t_{0}\right)\right) ; \varphi\left(\infty, t_{0}\right)$ - the final value of the creep coefficient, $a_{1}$ - the distance from the extreme tension fibre of element to the centre of gravity of the tension reinforcement.

Equivalent cross-section area of the T-beam:

$$
A=b_{e f f} h_{f}+b_{w} h_{w}+\left(\alpha_{e}-1\right) A_{s, \min }
$$


Distance from the extreme tension fibre of element to the neutral axis of the equivalent cross-section:

$$
v^{\prime}=\frac{S_{x}}{A}
$$

Second moment of area of the equivalent cross-section in phase I (uncracked):

$$
I_{I}=\frac{b_{e f f} h_{f}^{3}}{12}+b_{e f f} h_{f}\left(v^{\prime}-\frac{h_{f}}{2}\right)^{2}+\frac{b_{w} h_{w}^{3}}{12}+b_{w} h_{w} \cdot\left(v^{\prime}-h_{f}-\frac{h_{w}}{2}\right)^{2}+\left(\alpha_{e}-1\right) A_{s, \text { min }}\left(v^{\prime}-a_{1}\right)^{2}
$$

The section modulus of equivalent cross-section:

$$
W_{x}=\frac{I_{I}}{v^{\prime}}
$$

The height of the compression zone in phase II (cracked) can be determined from formula (7.1) given in [23]:

$$
x_{I I}=d\left(\sqrt{\left(\alpha_{e}-1\right) \rho_{l}\left(\left(\alpha_{e}-1\right) \rho_{l}+2\right)}-\left(\alpha_{e}-1\right) \rho_{l}\right)
$$

where: $\rho_{1}$ - reinforcement ratio for longitudinal reinforcement; $\rho_{1}=A_{\mathrm{s}, \min } /\left(b_{\mathrm{w}} \cdot d\right)$.

If $x_{\mathrm{II}}>h_{\mathrm{w}}$ the cross-section is actually T-shaped and the height of the compression zone should be determined by solving a quadric equation:

$$
\left(\alpha_{e}-1\right) A_{s, \min }\left(d-h_{w}-x\right)-b_{w} h_{w}\left(\frac{h_{w}}{2}+x\right)-b_{e f f} x \frac{x}{2}=0
$$

where: $x$ - the height of the part of compression zone located only in the flange of T-section.

The height of the compression zone is then:

$$
x_{I I}=x+h_{w}
$$

By knowing the section modulus determined by formula (15) and the height of the compression zone in phase II - formula (16) or (18), the minimum cross-sectional area of the tension reinforcement can be determined from formula (10).

The following parameters were assumed and calculated: $d=70 \mathrm{~cm}$ (the same for the dimensioning of the reinforcement in the span and on supports); $f_{\mathrm{cd}}=16.67 \mathrm{MPa}$; $f_{\text {ctm }}=2.6 \mathrm{MPa} ; \lambda=0.8 ; \eta=1.0 ; \varepsilon_{\mathrm{cu} 3}=0.0035 ; f_{\mathrm{yk}}=500 \mathrm{MPa} ; f_{\mathrm{yd}}=434.78 \mathrm{MPa} ; E_{\mathrm{s}}=200 \mathrm{GPa}$; $\xi_{\text {eff,lim }}=0.493$.

The result of the strict minimum cross-sectional area of the tension reinforcement (10) can be compared to that given in standard formula (7). Then the equivalent rectangular cross-section corresponding to the T-section can be determined. The difference in the minimum cross-sectional area of the tension reinforcement determined between formula (10) and (7) can be presented in relation $b_{\mathrm{t}} / b_{\mathrm{w}}$, which is shown in Table 5.

As shown in Table 5, the minimum cross-sectional area of the tension reinforcement determined from formula (10) differs from that determined from formula (7) on the assumption that $b_{\mathrm{t}}=b_{\mathrm{w}}$ (assuming calculations for a rectangular cross-section - variant 1 ). In the case of variant 2 of the calculations, the difference is more than five times, for the calculations in variant 3, 4 and 5, depending on the section under consideration, the difference is not more than three times. For variant 6 of the calculations, the difference is slightly greater than three times. 
Table 5. Minimum cross sectional area of reinforcement with specified of width $b_{\text {eff }}$ and $b_{\mathrm{t}}$

\begin{tabular}{|c|c|c|c|c|c|c|c|}
\hline & Parameter & Variant 1 & Variant 2 & Variant 3 & Variant 4 & Variant 5 & Variant 6 \\
\hline \multirow{4}{*}{$\begin{array}{l}\text { External } \\
\text { support }\end{array}$} & $\begin{array}{l}A_{\text {smin }}\left[\mathrm{cm}^{2}\right] \\
\text { eq. }(10)\end{array}$ & 2.21 & 14.58 & 4.41 & 4.58 & 2.21 & 9.61 \\
\hline & $b_{\mathrm{eff}}[\mathrm{cm}]$ & - & 400.0 & 84.0 & 88.4 & 30.0 & 230.0 \\
\hline & $\begin{array}{l}b_{\mathrm{t}}[\mathrm{cm}] \\
\text { eq. (7) }\end{array}$ & 23.4 & 154.0 & 46.6 & 48.4 & 23.4 & 101.5 \\
\hline & $b_{\mathrm{t}} / b_{\mathrm{w}}$ & 0.78 & 5.13 & 1.55 & 1.61 & 0.78 & 3.38 \\
\hline \multirow{4}{*}{$\begin{array}{l}\text { Inner } \\
\text { support }\end{array}$} & $\begin{array}{l}A_{\text {smin }}\left[\mathrm{cm}^{2}\right] \\
\text { eq. }(10)\end{array}$ & 2.21 & 14.58 & 6.45 & 8.08 & 6.45 & 9.61 \\
\hline & $b_{\text {eff }}[\mathrm{cm}]$ & - & 400.0 & 138.0 & 184.0 & 138.0 & 230.0 \\
\hline & $\begin{array}{l}b_{\mathrm{t}}[\mathrm{cm}] \\
\text { eq. (7) }\end{array}$ & 23.4 & 154.0 & 68.2 & 85.3 & 68.2 & 101.5 \\
\hline & $b_{\mathrm{t}} / b_{\mathrm{w}}$ & 0.78 & 5.13 & 2.27 & 2.84 & 2.27 & 3.38 \\
\hline
\end{tabular}

Tables 6, 7 and 8 shows the reinforcement dimensioning due to bending for: the external support, the span and the inner support respectively. In each cases (except for the reinforcement at the external support in variant 2 of the calculation) the cross-sectional area of the tensile reinforcement determined due to bending in ULS is larger than the minimum cross-sectional area of the tension reinforcement - formula (10). Moreover the assumed cross-sectional area of tensile reinforcement $A_{\text {s1,prov }}$ in the span and on the inner support in each of the calculation variants is equal, which proves that from a practical point of view (reinforcement made directly on the construction site) the calculation variant is of little importance. The difference occurs on the extreme support, however it is shown for the calculations in variant 1 and 2, which may be considered too far-reaching simplification in the construction modelling.

Table 6. Dimensioning of the reinforcement on the external support

\begin{tabular}{|c|c|c|c|c|c|c|}
\hline Parameter & Variant 1 & Variant 2 & Variant 3 & Variant 4 & Variant 5 & Variant 6 \\
\hline$M_{\mathrm{Ed}}[\mathrm{kNm}]$ & 407.05 & 327.99 & 336.33 & 339.5 & 333.28 & 340.27 \\
\hline$b[\mathrm{~cm}]$ & 30.0 & 30.0 & 30.0 & 30.0 & 30.0 & 30.0 \\
\hline $\begin{array}{l}\mu_{\text {eff }}[-] \\
\text { eq. (3) }\end{array}$ & 0.166 & 0.134 & 0.137 & 0.139 & 0.136 & 0.139 \\
\hline $\begin{array}{l}\xi_{\text {eff }}[-] \\
\text { eq. (4) }\end{array}$ & 0.183 & 0.144 & 0.148 & 0.150 & 0.147 & 0.150 \\
\hline$\xi_{\mathrm{eff}} \leq \xi_{\mathrm{eff}, \lim }$ & yes & yes & yes & yes & yes & yes \\
\hline $\begin{array}{l}A_{\mathrm{s} 1}\left[\mathrm{~cm}^{2}\right] \\
\text { eq. (6) }\end{array}$ & 14.72 & 11.61 & 11.94 & 12.06 & 11.82 & 12.09 \\
\hline $\begin{array}{l}A_{\text {smin }}\left[\mathrm{cm}^{2}\right] \\
\text { eq. }(10)\end{array}$ & 2.21 & 14.58 & 4.41 & 4.58 & 2.21 & 9.61 \\
\hline$A_{\mathrm{s} 1} \geq A_{\mathrm{smin}}$ & yes & no & yes & yes & yes & yes \\
\hline$A_{\mathrm{s} 1, \mathrm{prov}}\left[\mathrm{cm}^{2}\right]$ & $\begin{array}{l}5 \phi 20 \\
15.71\end{array}$ & $\begin{array}{l}5 \phi 20 \\
15.71\end{array}$ & $\begin{array}{l}4 \phi 20 \\
12.57\end{array}$ & $\begin{array}{l}4 \phi 20 \\
12.57\end{array}$ & $\begin{array}{l}4 \phi 20 \\
12.57\end{array}$ & $\begin{array}{l}4 \phi 20 \\
12.57\end{array}$ \\
\hline
\end{tabular}


Table 7. Dimensioning of the reinforcement in the span

\begin{tabular}{|c|c|c|c|c|c|c|}
\hline Parameter & Variant 1 & Variant 2 & Variant 3 & Variant 4 & Variant 5 & Variant 6 \\
\hline$M_{\mathrm{Ed}}[\mathrm{kNm}]$ & 357.17 & 399.56 & 405.06 & 394.94 & 402.29 & 393.33 \\
\hline$b[\mathrm{~cm}]$ & 30.0 & 400.0 & 230.0 & 214.8 & 230.0 & 230.0 \\
\hline $\begin{array}{l}\mu_{\text {eff }}[-] \\
\text { eq. (3) }\end{array}$ & 0.146 & 0.012 & 0.022 & 0.023 & 0.021 & 0.021 \\
\hline $\begin{array}{l}\xi_{\text {eff }}[-] \\
\text { eq. }(4)\end{array}$ & 0.158 & 0.012 & 0.022 & 0.023 & 0.022 & 0.021 \\
\hline$\xi_{\text {eff }} \leq \xi_{\text {eff,lim }}$ & yes & yes & yes & yes & yes & yes \\
\hline $\begin{array}{l}A_{\mathrm{s} 1}\left[\mathrm{~cm}^{2}\right] \\
\text { eq. (6) }\end{array}$ & 12.74 & 13.21 & 13.46 & 13.13 & 13.36 & 13.06 \\
\hline $\begin{array}{l}A_{\text {smin }}\left[\mathrm{cm}^{2}\right] \\
\text { eq. }(10)\end{array}$ & 2.84 & 2.84 & 2.84 & 2.84 & 2.84 & 2.84 \\
\hline$A_{\mathrm{s} 1} \geq A_{\mathrm{smin}}$ & yes & yes & yes & yes & yes & yes \\
\hline$A_{\mathrm{s} 1, \mathrm{prov}}\left[\mathrm{cm}^{2}\right]$ & $\begin{array}{l}5 \phi 20 \\
15.71\end{array}$ & $\begin{array}{l}5 \phi 20 \\
15.71\end{array}$ & $\begin{array}{l}5 \phi 20 \\
15.71\end{array}$ & $\begin{array}{l}5 \phi 20 \\
15.71\end{array}$ & $\begin{array}{l}5 \phi 20 \\
15.71\end{array}$ & $\begin{array}{l}5 \phi 20 \\
15.71\end{array}$ \\
\hline
\end{tabular}

Table 8. Dimensioning of the reinforcement on the inner support

\begin{tabular}{lllllll}
\hline Parameter & Variant 1 & Variant 2 & Variant 3 & Variant 4 & Variant 5 & Variant 6 \\
\hline$M_{\mathrm{Ed}}[\mathrm{kNm}]$ & 597.79 & 632.31 & 603.61 & 620.34 & 614.74 & 627.28 \\
\hline$b[\mathrm{~cm}]$ & 30.0 & 30.0 & 30.0 & 30.0 & 30.0 & 30.0 \\
\hline $\begin{array}{l}\mu_{\text {eff }}[-] \\
\text { eq. }(3)\end{array}$ & 0.244 & 0.258 & 0.246 & 0.253 & 0.251 & 0.256 \\
\hline $\begin{array}{l}\xi_{\text {eff }}[-] \\
\text { eq. }(4)\end{array}$ & 0.284 & 0.304 & 0.288 & 0.297 & 0.294 & 0.301 \\
\hline $\begin{array}{l}\xi_{\text {eff }} \leq \xi_{\text {eff, lim }} \\
A_{\text {s1 }}\left[\mathrm{cm}^{2}\right]\end{array}$ & yes & yes & yes & yes & yes & yes \\
eq. $(6)$ & 22.90 & 24.51 & 23.17 & 23.94 & 23.68 & 24.27 \\
\hline $\begin{array}{l}A_{\text {smin }}\left[\mathrm{cm}^{2}\right] \\
\text { eq. }(10)\end{array}$ & 2.21 & 14.58 & 6.45 & 8.08 & 6.45 & 9.61 \\
\hline$A_{\mathrm{sl}} \geq A_{\text {smin }}$ & yes & yes & yes & yes & yes & yes \\
\hline$A_{\text {sl,prov }}\left[\mathrm{cm}^{2}\right]$ & $8 \phi 20$ & $8 \phi 20$ & $8 \phi 20$ & $8 \phi 20$ & $8 \phi 20$ & $8 \phi 20$ \\
\hline
\end{tabular}

\section{Summary and conclusions from the calculations}

As shown by the comparative analysis of bending moments, the method of defining the flange width of the T-section has no significant impact on the results. Modelling the beam of a frame with variant 3, 4 and 5 may present problems in defining the section along the length of the element, especially for more complex structures. In addition, it generates a considerable amount of work time. Variant 1 of the calculations (rectangular beam) is too approximate. The bending moment and the elastic deflection values differ significantly from those obtained with T-section of the frame beam. Variant 2 underestimates the deflection values, which may disqualify this solution in the design of reinforced concrete structures due to the Serviceability Limit State in later calculations. Variant 6 of the calculations (recommended by [11]) is rational in terms of the values of internal forces, as well as in terms of time of structure definition in computer program. However, it should be emphasized that the effective width should be determined for all cross-sections along the length of the beam due to the calculations of reinforcement at the Ultimate Limit State, shear between web and flanges and spread of reinforcement on the intermediate support of continuous beams. 
Furthermore, significant differences in the minimum cross-sectional area of the tension reinforcement should be noted. In each case of T-section beams with a flange in the tension zone, this value should be determined precisely. However, from the engineering point of view, a simplified criterion can be assumed - if the cross-sectional area of the tension reinforcement in element $A_{\mathrm{s} 1}$ (value from calculations in the Ultimate Limit State) for flange in tension is more than three times larger than the minimum cross-sectional area of the tension reinforcement determined from the standard formula - as for rectangular cross-section (7) the exact verification of the $A_{\mathrm{s}, \min }$ can be omitted. However it may be the decisive condition for the section resistance and the minimum cross-sectional area of the tension reinforcement must be determined precisely.

\section{References}

[1] Ambroziak A., Kłosowski P., Autodesk Robot Structural Analysis Podstawy obliczeń. Wydawnictwo Politechniki Gdańskiej, Gdańsk, 2013.

[2] Ambroziak A., Kłosowski P., Autodesk Robot Structural Analysis Wymiarowanie konstrukcji stalowych i żelbetowych. Wydawnictwo Politechniki Gdańskiej, Gdańsk, 2016.

[3] Solarczyk M.T., Ambroziak A. „Simplified method of applying loads to flat slab floor structural models", in 2nd Baltic Conference for Students and Young Researchers BalCon 2018, Gdańsk, 2018. https://doi.org/10.1051/matecconf/201821903002

[4] Starosolski W., „Uwagi o obliczaniu belek w trakcie modelowania stropów płytowo-żebrowych”. Przeglad Budowlany, No. 9, p. 50-53.

[5] Kossakowski P., „Inżynierski problem komputerowego modelowania pracy żelbetowej płyty dwuprzęsłowej z uwzględnieniem sprężystej podatności belki”, Przegląd Budowlany, No. 10, p. 19-24.

[6] Kossakowski P., „Uwzględnienie wpływu sprężystej podatności belek w numerycznym modelowaniu stropów żelbetowych”. Przegląd Budowlany, No. 11, p. 24-31.

[7] Godycki - Ćwirko T., Nagrodzka - Godycka K., Piotrkowski P., „Dome over the Gdynia seaport building". Archives of Civil Engineering, issue 60, no. 2, pp. 223-239. https://doi.org/10.2478/ ace-2014-0015

[8] Nagrodzka - Godycka K., Godycki - Ćwirko T., Wojdak R., „,Reinforced concrete thin wall dome after eighty years of operation in maritime climate environment", Structural Concrete, issue 5, no. 17, pp. 710-717. https://doi.org/10.1002/suco.201500180

[9] Wojdak R., „Żelbetowa konstrukcja wsporcza zadaszenia stadionu na EURO 2012 w Gdańsku”. Inżynieria Morska i Geotechnika, No. 2 (2012), p. 125-134.

[10] Ciesielczyk K., Szumigała M., Ścigałło J., „The numerical analysis of the effective flange width in T-section reinforced concrete beams", in Modern Building Materials, Structures and Techniques, MBMST 2016, Procedia Engineering, volume 172, 2017, pp. 178-185. https://doi.org/10.1016/j. proeng.2017.02.047

[11] PN-EN 1992-1-1:2008. Eurokod 2: Projektowanie konstrukcji z betonu. Część 1-1: Reguty ogólne i reguly dla budynków.

[12] Knauff, M. Grzeszykowski, B. Golubińska, A., „Minimum reinforcement for crack width control in RC tensile elements", Archives of Civil Engineering, issue 65, no. 1, pp. 111-128. http://doi. org/10.2478/ace-2019-0008

[13] Knauff, M. Grzeszykowski, B. Golubińska, A., „Minimum reinforcement for crack width control - design example". Inżynieria i Budownictwo, annual 74, no. 5, 2018, pp. 232-236.

[14] Knauff, M. Grzeszykowski, B. Golubińska, A., „Minimum reinforcement for crack width control in RC elements subjected to small eccentricity tension". Inżynieria i Budownictwo, annual 74, no. 3, 2018, pp. 134-138. 
56 Influence of effective width of flange on calculation and reinforcement dimensioning...

[15] Knauff, M. Golubińska, A., „Simple method for determining minimum reinforcement area to control cracking". Inżynieria i Budownictwo, annual 69, no. 6, 2013, pp. 330-333.

[16] Knauff M. et al., Podstawy projektowania konstrukcji żelbetowych i sprężonych wedlug Eurokodu 2. Dolnośląskie Wydawnictwo Edukacyjne, Wrocław, 2006.

[17] PN-B 03264:2002. Konstrukcje betonowe, żelbetowe i sprężone. Obliczenia statycznie i wymiarowanie.

[18] Kargol W., Szerafin J., „The consequences of the choice of design standards for the use of material on the example of glued laminated roof beam", Budownictwo i Architektura, vol. 8, no. 1, pp. 35-45. https://doi.org/10.35784/bud-arch.2256

[19] PN-EN 1991-1-1:2004. Eurokod 1: Oddziatywania na konstrukcje. Część 1-1: Oddziatywania ogólne Ciężar objętościowy, ciężar właściwy, obciążenia użytkowe w budynkach.

[20] PN-EN 1990:2004. „Eurokod 0: Podstawy projektowania konstrukcji.”.

[21] Knauff M., Obliczanie konstrukcji żelbetowych wedtug Eurokodu 2. Wydawnictwo Naukowe PWN, Warszawa, 2012.

[22] Łapko A., Jensen B. Ch., Podstawy projektowania i algorytmy obliczeń konstrukcji żelbetowych. Arkady, Warszawa, 2009.

[23] Solarczyk M.T., „Szerokość rozwarcia rys w konstrukcjach żelbetowych według PN-EN 1992-1-1:2008 oraz PN-B 03264:2002", in Współczesne budownictwo w badaniach młodych naukowców, Wydawnictwo Politechniki Gdańskiej, Gdańsk, 2017. 